\title{
Late Proterozoic paleomagnetism and tectonic models: a critical appraisal
}

\author{
Rob Van der Voo and Joseph G. Meert \\ Department of Geological Sciences, University of Michigan, Ann Arbor, MI 48109-1063, USA
}

(Received February 1, 1990; accepted after revision July 26, 1990)

\begin{abstract}
Van der Voo, R. and Meert, J.G., 1991. Late Proterozoic paleomagnetism and tectonic models: a critical appraisal. In: R.J. Stern and W.R. Van Schmus (Editors), Evolution in the late Proterozoic. Precambrian Res., 53: 149-163.

Interpretations of Proterozoic orogenic belts in terms of plate tectonic processes have been widely divergent. Published models range between the extremes of no relative motions between continental nuclei (implying ensialic orogenic processes) on the one hand, to large-scale relative motions with oceans opening and closing (resulting in continent-continent collisions ) on the other hand. Paleomagnetic data can, in theory, contribute significantly to this debate; however, as shown in this paper, several tectonic interpretations on the basis of paleomagnetic data have been premature. A critical continent in many of the previous models is Africa. In order to test hypotheses, for instance, for the late Proterozoic-Cambrian Pan African orogeny, a compilation of paleopoles has been made for Africa, with age ranges falling fully or partially within the interval of 1150 to $500 \mathrm{Ma}$. A quantitative comparison of the quality of this African dataset with the Phanerozoic poles for North American and Europe shows that the late Proterozoic paleopoles of Africa generally have very low reliability. It appears that the data from other Gondwana continents are equally unreliable and even less abundant. This means that currently the dataset of Gondwanaland cannot be used with confidence for the testing of tectonic models such as the Precambrian supercontinent, at least for the time after $1150 \mathrm{Ma}$. Well-dated late Proterozoic paleopoles from the three cratonic nuclei within Africa (Congo, Kalahari, West Africa) define relatively short apparent polar wander path segments, but each with different age ranges. This implies that they cannot be compared with each other to test relative motions between the cratonic nuclei and that a choice between ensialic and ensimatic models for the Pan African orogenic belts cannot yet be based on paleomagnetic data. While this does not imply that the tectonic models (e.g. those of Piper and McWilliams) are wrong, it does mean that substantial paleomagnetic support for them will have to wait more and higherquality paleopole determinations with better dating precision.
\end{abstract}

\section{Introduction}

For many investigators studying Precambrian tectonics there is little question that the plate tectonic paradigm explains many features of the structure, facies and tectonic regimes of the Proterozoic shields of the world. Especially for the Canadian Shield, publications dealing with Proterozoic sutures, continent-continent collisions and, by inference, seafloor spreading and subduction, are quite numerous (e.g. Camfield and Gough, 1977; Gibb et al., 1980; Hoffman, 1988 and the many references therein). While paleomagnetic data have been influential in the documentation of plate tectonic processes during the Phanerozoic, there is hardly any firm support from fossil remanence for Proterozoic plate tectonic scenarios such as oceans closing between cratonic elements through subduction or for continent-continent collisions. For North America this is due, in part, to the difficulty of obtaining enough early Proterozoic (pre-Hudsonian) paleopoles from the different tectonic elements that constitute Hoffman's (1988) United Plates of America. After an early, and 
no longer viable, proposal invoking paleomagnetic support for a Grenville-Superior collision (Irving et al., 1972) and a controversial attempt to delineate plate convergence between the Superior and Slave provinces with paleomagnetic poles (Cavanaugh and Seyfert, 1977; Roy et al., 1978), some workers have recently revived the issue with promising results (e.g. Symons, 1989); however, the evidence remains meager.

For other continents, paleomagnetists have been equally cautious and conservative in their interpretations of Precambrian apparent polar wander path in plate tectonic terms; exceptions are formed by the papers of Onstott and Hargraves (1981), Onstott et al. (1984), and McWilliams (1981). Although others have argued as well that there is paleomagnetic support for Proterozoic relative motions (e.g. Burke et al., 1976), the predominant sentiment has been that the assembly of tectonic nuclei within a shield, such as found in Africa, has been a relatively permanent Proterozoic feature (e.g. McElhinny and McWilliams, 1977; McWilliams and Kröner, 1981). While such models, based on paleomagnetism, may envision limited rifting and separation between cratonic nuclei, and do not necessarily argue against the plate tectonic scheme, the mobile belts between the nuclei are envisioned to have had no appreciable seafloor spreading or subduction of oceanic crust: the orogenic belts fit the definition of ensialic orogenies (McWilliams and Kröner, 1981). Kröner $(1977,1980,1982)$ has summarized the tectonic models underlying this concept.

For a discussion of late Proterozoic plate motions, West Gondwana (Africa and South America) is a key continent: it is traversed by late Proterozoic (Pan African) orogenic belts that separate older nuclei; relative movements between these nuclei can be tested with a good paleomagnetic data set. In contrast, other paleomagnetically well-studied continents, such as North America and the Baltic Shield-Russian Platform do not provide opportunities to test late Proterozoic plate tectonic models, because even if they do contain younger Proterozoic mobile belts, these are generally located at the cratonic margins. While the models advanced by the paleomagnetists have generally not included large relative motions between Africa's cratonic nuclei, interpretations of geological features in plate tectonic terms have included arguments in favor as well as against. Many papers describe the Pan African mobile belts as being the result of plate motions and the formation of oceanic crust, i.e., as ensimatic orogenies (Black, 1978; Black et al., 1979; Barnes and Sawyer, 1980; Leblanc and Lancelot, 1980; Shackleton et al., 1980; Unrug, 1983; Andersen and Unrug, 1984; Porada, 1989; Key et al., 1989), whereas others have argued against this and favored ensialic models (e.g. Shackleton, 1976; Kröner, 1977; Martin and Porada, 1977). It is clear that at this time there is no consensus about the tectonic setting of the Pan African belts.

On a more global scale, it has been proposed by Piper (1976) that a single supercontinent existed for the entire Proterozoic interval and consisted of the Gondwanan, North American (Laurentian), North and East European (Baltican) and Siberian continental shields. The paleomagnetic evidence for this supercontinent has been presented most recently by Piper (1987) and incorporates all paleopoles for the Proterozoic, which in his model are presented as falling systematically on a common apparent polar wander path according to their assigned ages. The only allowance for relative motions made by Piper in this model is for a brief readjustment period around $1 \mathrm{Ga}$, when Baltica and Laurentia and East and West Gondwana fragments rearranged themselves into a modified configuration (Fig. 1). In contrast to the late Proterozoic supercontinent model, McWilliams (1981) has argued that the Paleozoic configuration of East and West Gondwana did not exist prior to the latest Precambrian-early Paleozoic Pan African orogeny. 
a)
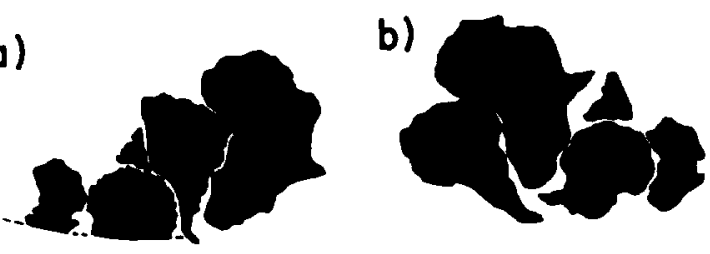

Fig. 1. Cartoon of continental reconstructions of Gondwana (from Piper, 1987) for (a) times before $1000 \mathrm{Ma}$, and (b) late Precambrian-Paleozoic times after $700 \mathrm{Ma}$ (or earlier; this reconstruction is called "Gondwanaland A" and is similar to that of Smith and Hallam, 1970).

There are thus two outstanding problems for paleomagnetism to resolve, in so far as late Proterozoic time is concerned. First, it is a matter of great importance to discover whether or not there was large-scale relative motion between the major continental cratons and when this drift occurred (such as between North America and West Africa or between East and West Gondwana ). Second, it is a matter of debate whether individual cratonic nuclei within a continent, such as Africa, underwent largescale relative motions with respect to each other. The evidence accumulated thus far from paleomagnetism and from other geological disciplines is conflicting, as discussed above.

To resolve such questions, a good paleomagnetic data base is necessary. A look at the available late Proterozoic paleopoles for Africa is very revealing and will form the first part of this paper. Evaluation of late Proterozoic data from the perspective of the much better studied Phanerozoic shows that the quality is generally too low to make any significant conclusions. The second aspect of Precambrian paleomagnetic analysis that we wish to highlight deals with problems in the construction of common global apparent polar wander paths, such as carried out by Piper (1987).

\section{Reliability criteria}

There are three basic criteria for a good paleomagnetic paleopole determination that are generally recognized: structural control, age of the paleopole, and paleomagnetic laboratory treatment of sufficient samples. It should be noted that if some criteria are not satisfied, the paleopole may still be a valid record of the ancient field, while poles that meet more than the minimum criteria may occasionally turn out to be seriously in error because the magnetizations were erroneously diagnosed as primary and in need of structural correction. Beyond the three basic criteria, moreover, there is a wide variety of individual preferences, and even for the basic "requirements" mentioned above, the minima are not always uniformly set in the literature. The acceptable minimum in terms of the number of sites or samples, the allowable error limits on an age determination, and the minimum level of laboratory treatment (demagnetization) are all subject to variable rejection criteria, depending on the analysis performed. It is easier to know when a paleopole has been well determined than it is to know with any certainty that it is flawed.

In a recent paper (Van der Voo, 1990), seven reliability criteria have been proposed, in addition to a basic requirement that demagnetization must have been performed on all samples. This last requirement excludes many early results in the 1950's and 1960's that were based on untreated natural remanent magnetizations (NRM's) only. Although these criteria are published, they are repeated here for completeness' sake. They are:

(1) A well-determined age for the rock unit from which the results are derived, and a presumption that the magnetization is of about the same age. Our preference is that the age limits for Precambrian results should be set to $\pm 4 \%$ or $\pm 40 \mathrm{Ma}$, whichever is smaller, because any uncertainty range larger than that would diminish the usefulness of the result in terms of tectonic interpretations when the magnitude of typical apparent polar wander is taken into account. For a Precambrian rock unit of $2000 \pm 40 \mathrm{Ma}$, the total uncertainty of $80 \mathrm{Ma}$ would imply an angular uncertainty of \pm 16 degrees, when a typical Cenozoic apparent polar wander water of 32 degrees per $80 \mathrm{Ma}$ is 
assumed. This angular uncertainty corresponds to the maximum A95 discussed below for criterion 2.

(2) A sufficient quantity of entries (samples) and adequate statistical precision. Our preference is to have this criterion satisfied when the number of samples used is greater than 24 , and the precision parameter, $k$ (or $K$ for the mean of virtual geomagnetic poles), is greater than 10.0 and alpha95 (or A95) is less than 16 degrees. Previous compilations have used smaller as well as larger limits; the specific numbers selected allow for a good number of paleopoles to satisfy this criterion.

(3) Adequate demagnetization. Results obtained without demagnetization of all samples should not be used for tectonic analyses and have not been included. However, even if demagnetization was performed, it cannot be assumed that magnetic components are appropriately isolated, e.g., in the case of blanket treatment in low alternating fields (AF) or using low temperatures only. Only when vector subtraction is performed, as illustrated by orthogonal vector diagrams (Zijderveld, 1967), by the use of stereonets giving change in direction combined with intensity decay plots, or by principal component analysis (PCA; Kirschvink, 1980), can one be assured that magnetic components are isolated as well as possible.

(4) Field tests that constrain the age of magnetization, such as the fold, conglomerate and contact tests, may not always be possible because of the limitations of outcrop and field settings. However if such tests are positive and statistically significant, they satisfy this criterion and, hence, make paleopoles more reliable.

(5) Structural control, including a presumption that the area studied belonged to the craton or tectonic block involved, should be complete for this condition to be met. For orogenic belts, results from intrusives with ages older than the last tectonic phase or results from thrust sheets, that may have rotated, will not satisfy this criterion.

(6) The presence of reversals is a powerful test that enough time has lapsed for secular variation to be averaged. Moreover, antipodal reversals generally preclude a systematic bias caused by a small but unrecognized overprint. Although reversals are no guarantee that a rock unit is not remagnetized, they add reliability to a result and, hence, will satisfy this sixth criterion.

(7) No suspicion of remagnetization and no resemblance to paleopoles from rocks of (much) younger age. Unless a fold test is available to constrain the (early) acquisition age of magnetization, such a resemblance is usually a strong indication that remagnetization has occurred. For older Precambrian results it will be difficult to meet this criterion, given that with increasing age and increasing apparent polar wander path length for younger times, the chance of resembling a younger paleopole also strongly increases.

Based on these criteria, an "information" (or quality) factor, $Q$, can be assigned to each paleopole that simply tells how many out of a maximum of seven criteria are satisfied. Even for the best-studied time intervals and continents, few paleomagnetic results satisfy all seven criteria; it is, for instance, extremely rare to find Early Permian rocks that show reversals. For the Paleozoic of cratonic North America, for instance, only 2 results have a $Q=7$ (Van der Voo, 1990). Thus, we emphasize that these criteria, when satisfied, do add to the reliability of a result, but also stress that a result may still be reliable even if several criteria are not met.

As we will see later, no late Proterozoic results from Africa pass all seven (or even six out of seven) criteria. Others have noted similar problems with the Proterozoic paleomagnetic results (Idnurm and Giddings, 1988). In a review of Australian Precambrian results, they state “... (our) criteria may be regarded as rather lenient. Despite this, application of the scheme to the poles allows only four poles to be regarded as key poles. In a dramatic manner, this emphasizes the generally low quality 
of Australian Precambrian paleomagnetic data".

\section{The late Proterozoic paleopoles for Africa}

We have compiled from the literature the available paleomagnetic results for African rocks whose ages are reported to fall completely or partly within the time interval of 1150 to $500 \mathrm{Ma}$ (Table 1). This is the interval of primary importance in testing tectonic models for the Pan African orogenic cycle, which begins after the Middle Proterozoic Kibaran and Irumide cycles. The 64 poles with ages ranges that overlap with this time interval are shown in Fig. 2a. Some paleopoles previously included in compilations for this interval are now known to be older. They have been listed separately in Table 1.

When an attempt is made to construct an apparent polar wander path (APWP) through these poles, the first problem one encounters is that only 15 paleopoles are sufficiently well dated (Reliability column 1 in Table 1; Fig. $2 b)$. Several well dated poles for the cratons and the Pan African mobile belts fall between 460 and $630 \mathrm{Ma}$ and are fairly scattered. Older well-dated poles have age groups around 1000 Ma for the Kalahari craton and around $800 \mathrm{Ma}$ for the Congo craton (for outlines of the cratons, see Fig. 2a). Thus, it is immediately clear that a meaningful comparison between the more reliable portions of the individual APWP's for the main cratonic nuclei of Africa (heavy lines in Fig. 2b) is impossible, and that construction of a combined APWP for all of Africa has many degrees of freedom because of the large age uncertainties of the remaining paleopoles. The second problem is that the polarity of the paleomagnetic results is generally not known and, therefore, one faces choices between poles and antipoles in APWP construction. All results have been plotted in Fig. 2 in one arbitrarily chosen hemisphere, centered on $0 \mathrm{~N}, 340 \mathrm{E}$.

The average $Q$ factor for all 64 paleopoles of
Table 1 is low; histograms of $Q$ are presented in Fig. 3 for the late Proterozoic of Africa and, for comparison, for the Phanerozoic data of Europe and North America (Van der Voo, 1990 ). It can be seen at a glance that the late Proterozoic median $Q$ of 2.5 is much lower than the Phanerozoic median of 4.5. Thus, the reliability of the late Proterozoic African paleopoles is low not only because of dating inaccuracies, but also because the results meet few criteria such as those related to adequate demagnetization and structural control, let alone criteria based on positive field tests (only 2 poles satisfy criterion 4 in Table 1 ). Figure $2 \mathrm{c}$ shows the African late Proterozoic-Cambrian paleopoles with $Q=3$ or greater. Welldetermined and approximate ages (if ranging over no more than $150 \mathrm{Ma}$ ) are indicated. There is no clear pattern that emerges and one would be hard pressed to construct a common African APWP from this plot.

We conclude from this brief description of the current African late Proterozoic data base, that APWP construction for Africa as a whole cannot be regarded as rigorous or even defensible for tectonic purposes. African late Proterozoic APWP's published in the literature can only be considered as meaningful in terms of first attempts at bringing order to the data; they can neither be used for analyses of relative motions between Africa and other cratons (e.g. McWilliams, 1981), nor for tests of long-lived continental configurations of all the continental cratons (e.g. Piper, 1987), at least for the time after $1150 \mathrm{Ma}$.

For Africa's three cratonic nuclei, it is possible to construct meaningful APWP segments (see Fig. 2b) for short periods, but the three path segments thus obtained do not overlap in time and, hence, do not lend themselves to an analysis of relative motions between the three blocks.

What about the other Gondwana continents? We have already mentioned the opinions of Idnurm and Giddings (1988) about the Australian data; for South America, India, 


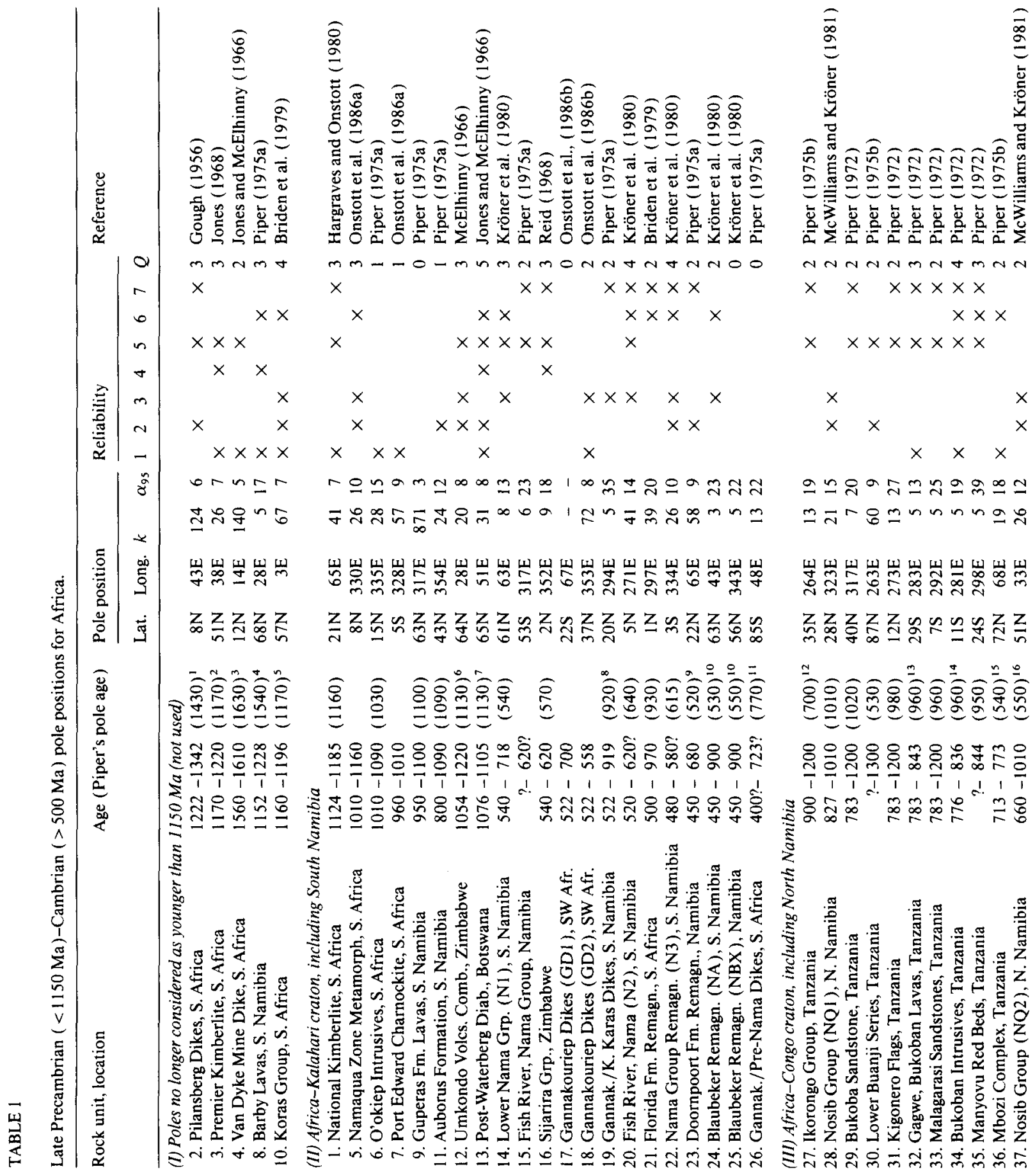




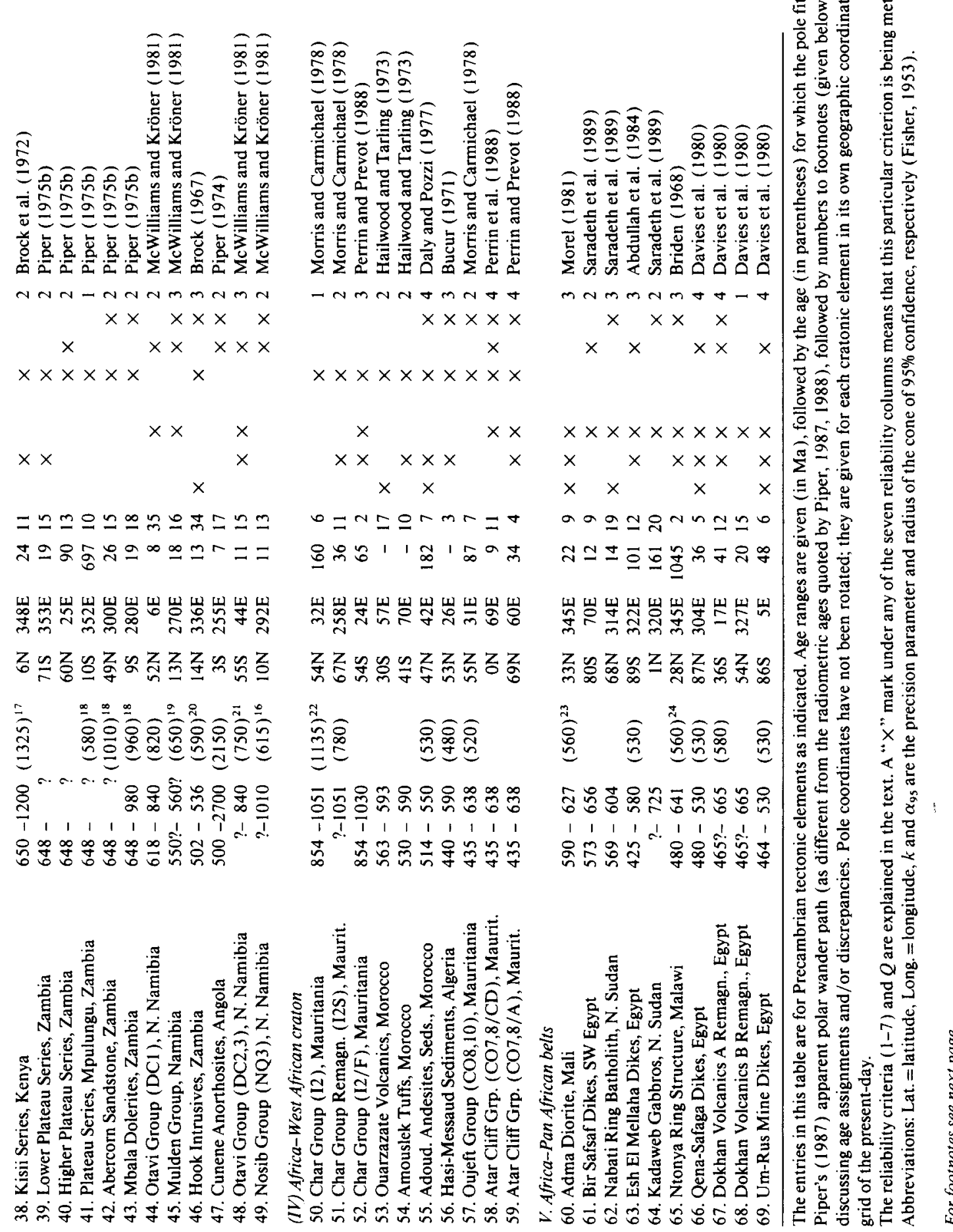




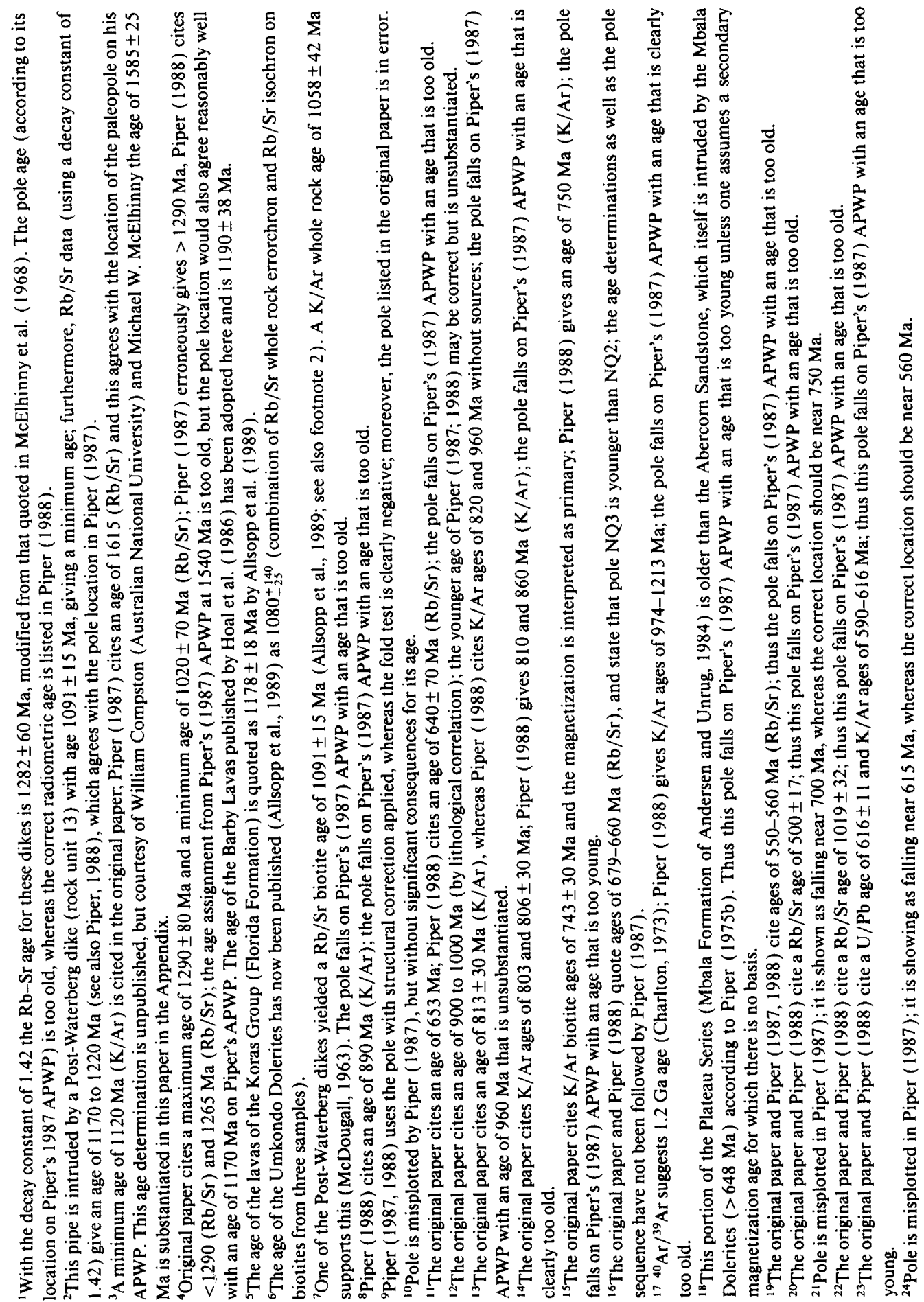




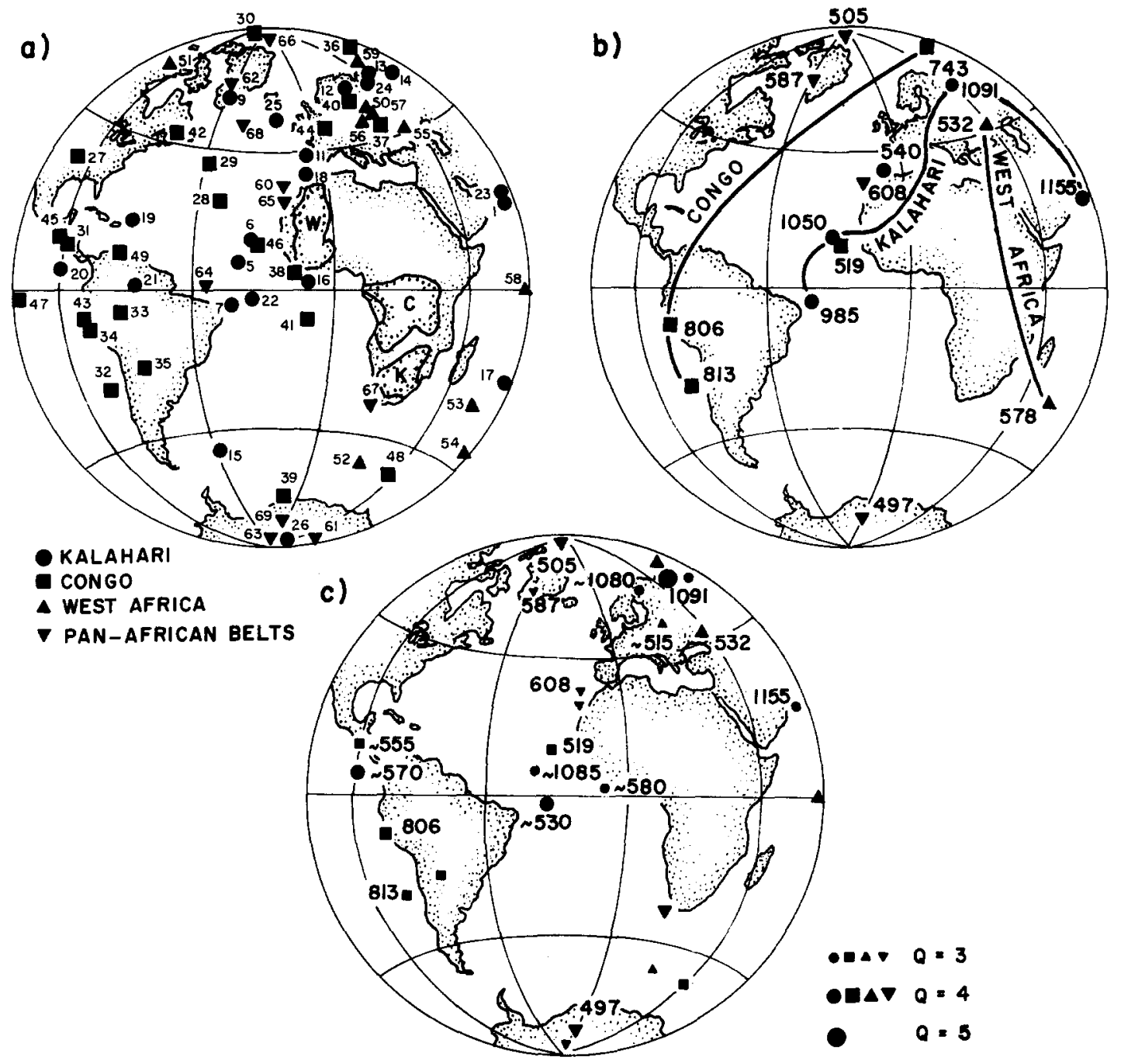

Fig. 2. Hemispheric plots, centered on 0N, 340E, with (a) all 64 poles as compiled for the late Proterozoic-Cambrian of Africa; the numbers correspond to those in Table 1. The West African $(W)$, Congo $(C)$ and Kalahari $(K)$ cratons are outlined. (b) The subset of well-dated poles which satisfy criterion 1 in Table 1, with mean age in Ma. Heavy lines connect those poles from the same cratonic nucleus that are less than $200 \mathrm{Ma}$ apart in age, in order to indicate approximate APWP segments for the three nuclei of Africa. Note that each of these segments is for a different time interval. (c) The subset of poles with $Q=3$ or greater. Approximate ages are labeled for poles for which the age range is less than $150 \mathrm{Ma}$ (e.g. $\sim 1085$ ) as well as for well-dated poles meeting criterion 1 (e.g. 519).

Antarctica and Madagascar, and also for China and Siberia the situation is even worse in terms of numbers of available paleopoles (see, e.g., fig. 3 of Irving and Lapointe, 1975). If paleomagnetism is to make a contribution to global Precambrian tectonic and paleogeographic problems, the data base for Africa (or other Gondwana continents) must be improved to the levels of those for the Precambrian of North America (e.g. Irving, 1979; Piper, 1987) and the Baltic Shield/Russian Platform (Pesonen et al., 1989). 

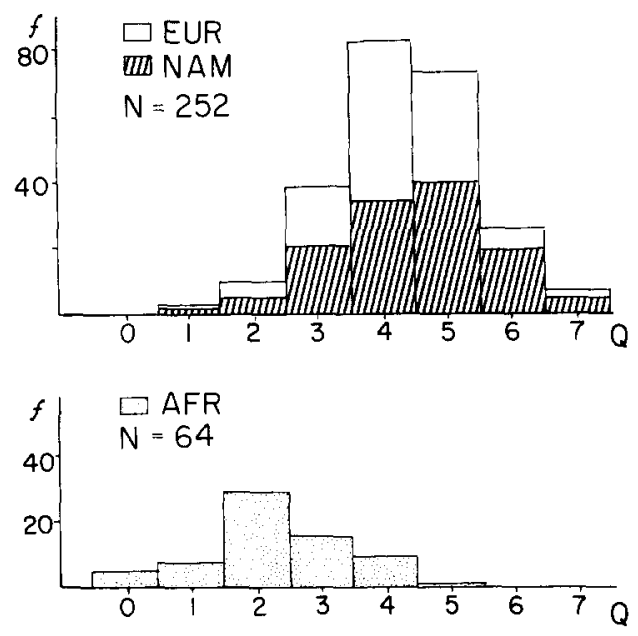

Fig. 3. Histograms of the quality factor, $Q$, as compiled in Table 1 for the late Proterozoic-Cambrian African poles (bottom) and, for comparison, for 252 North American and European Phanerozoic poles (top; from Van der Voo, 1990). Note that the median $Q$ is about 4.5 for the Phanerozoic dataset and only about 2.5 for the African late Proterozoic-Cambrian dataset.

\section{Can a common APWP for a long-lived Proterozoic supercontinent be constructed?}

As mentioned earlier, Piper (1976, 1987) has proposed that all continental nuclei were semi-permanently assembled in a supercontinent configuration (Fig. 1), and has detailed the paleomagnetic support for this model in a series of figures (Piper, 1987) that illustrate the common APWP segments with the individual paleopoles.

It is important to note that the paleomagnetic approach to test such a configuration is different from that attempted in the previous section. Once a supercontinent configuration is selected, the paleopoles of all continental nuclei must fall on a common APWP for the duration of the supercontinent assembly, in contrast to an approach which constructs several APWPs for separate tectonic elements which then are matched to each other. Not only must the poles fall on the common APWP, their age ranges must also fit the general age assignments of this APWP. The latter requirement can only be considered as rigorous if many of the paleopoles are well dated; unfortunately, many of the Precambrian poles are not.

Given that many Precambrian paleopoles are very poorly dated, we wish to note also that the particular APWP constructed by Piper (1987) allows almost any paleopole location to be incorporated. To illustrate this, Piper's pole path (i.e., swaths of finite width) has been digitized, with polarities inverted so that all portions of the APWP for the entire late Archean and Proterozoic fall on one hemisphere. The many loops and swings of this APWP cover nearly the entire hemisphere. There is nothing objectionable to this: indeed, it is entirely to be expected if one assumes that the perambulations of the Precambrian continent(s) were probably random and may have covered the entire globe. However, since the areas which are not covered by the late Archean and Proterozoic APWP are very small (as shown in Fig. 4), this also means that an undated paleopole will always fall somewhere on the common supercontinental APWP!

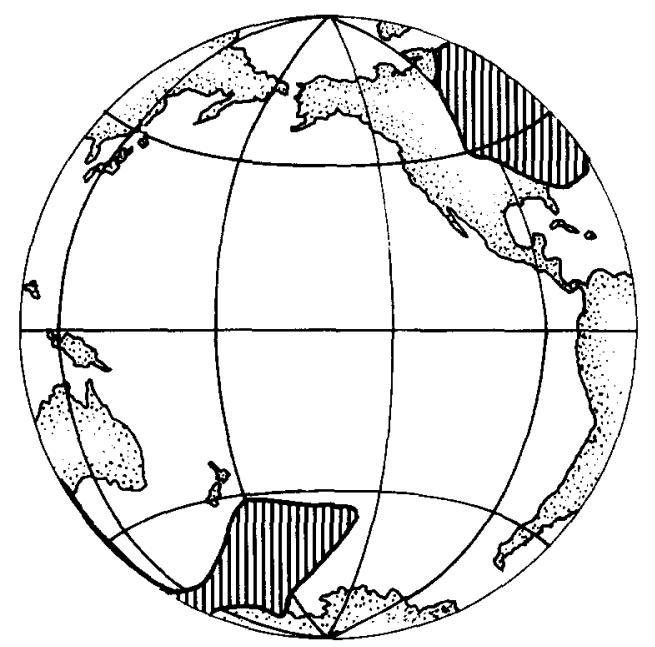

Fig. 4. Hemispheric plot of those areas (shaded) which are not covered by Piper's (1987) late Archean-Proterozoic APWP (actually a swath with finite width ), in North American coordinates. Polarities have been inverted for some time periods, in order to use only one hemisphere. This swath, with many loops and swings, traverses almost the entire hemisphere, as would be expected for Precambrian continental motions. However, this figure also illustrates that an undated (Precambrian) paleopole can always be located somewhere on the APWP. 

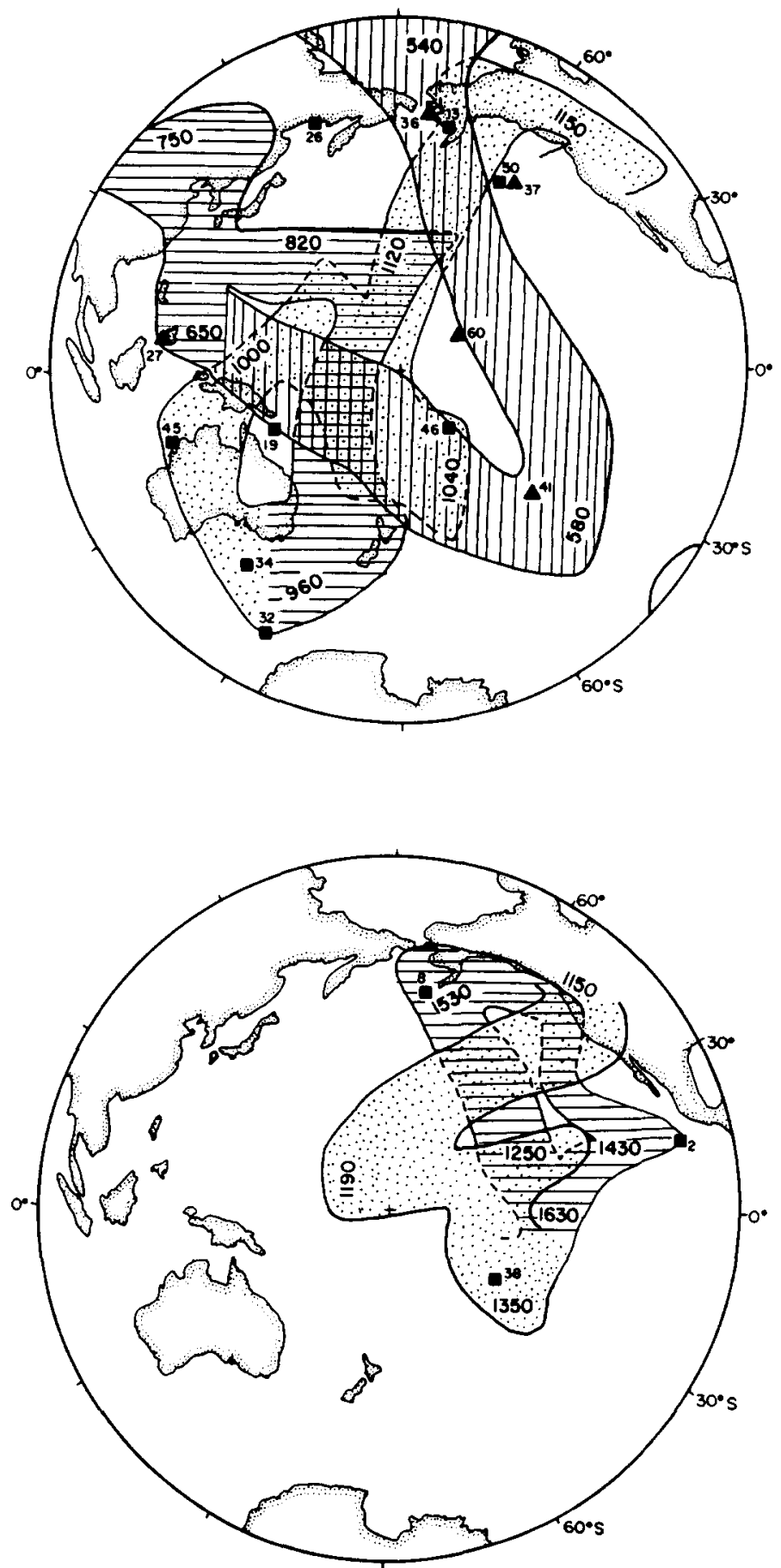

Fig. 5. Hemispheric plots of Piper's (1987) apparent polar wander path in North American coordinates from about 520 to $1150 \mathrm{Ma}$ (top) and 1150 to $1630 \mathrm{Ma}$ (bottom). Individual poles, identified by their numbers from Table 1, are plotted if their rock age is in significant disagreement with the pole age, i.e., the age assignment from the apparent polar wander path segment on which they fall. Squares (triangles) represent poles that have a pole age greater (less) than the rock age (see footnotes to Table 1). 
If a paleopole falls on an APWP segment, but with an age different from those assigned to that segment, it could be argued that either the supercontinent assembly is refuted, or that the paleopole's age (or location) is incorrectly determined. To test this, we have estimated the age of the APWP segment appropriate for the poles of Table 1, according to Piper's (1987) APWP for the supercontinent assembly and these age estimates are also listed in Table 1 (column 2). Of the total of 69 results (including the five older poles ), 53 were used by Piper in his figures; several of the remaining paleopoles were published subsequent to Piper (1987). Footnotes (e.g. 1, 4, 7, 8, 11-20, 22, 23 ) are added for each of the sixteen results where this age estimate is in disagreement with the ages generally assigned to the paleopoles in the original literature or with the ages given in Piper's database (1988). Seven of these 16 age discrepancies are for paleopoles with age constraints that meet criterion 1 . In addition, it was found that a couple of paleopoles were misplotted in Piper (1987), but without serious consequences.

It is possible, of course, that some of the age discrepancies noted in Table 1 will disappear with further geochronological work, or that we have overlooked some already published documentation that would allow Piper to assign ages different from those given in the original papers. However, we have generally not been able to find any documentation or argumentation to that effect in Piper's books (1987, 1988 ). In Figure 5 Piper's (1987) APWP is reproduced with those poles for which the radiometric (rock) ages do not match the ages assigned to the APWP segment on which they fall. It should be noted that the magnetization of a pole that falls on a younger segment may always be inferred as secondary; in contrast, a pole that falls on an APWP segment that is older than the rock age is more difficult to explain. The occurrences of the latter are listed in the footnotes; particularly pole numbers 32 , $34,38,45,46,50$ and 60 are noteworthy, al- though not all of these rocks are sufficiently well dated. Thus, we reiterate that it is not the issue at this time whether some or all of Piper's hypothesis is right or wrong, but rather that the scientific basis for a strong defense of the late Proterozoic unity of Africa and the Precambrian Supercontinent is not very substantial, because magnetization and age precision are lacking for more than $75 \%$ of the paleopoles, whereas in about $20 \%$ of the cases the paleopole age does not agree with the age assigned to the APWP segment on which it falls.

It appears, then, that at least for Africa's late Proterozoic-Cambrian paleopoles the fit between them and the common supercontinent APWP is only marginally successful. The bestdetermined Precambrian APWP is for the North American craton and it is clearly recognizable in Piper's path; the true test of the supercontinent assembly rests with the data from the Gondwanan and Asian tectonic elements. Since Africa has arguably the most abundant Precambrian paleopole dataset of all Gondwana continents, the partial failure of its late Proterozoic poles to match the common supercontinent APWP may be taken as a sign that the supercontinent hypothesis cannot yet be regarded as more than marginally supported on paleomagnetic grounds.

\section{Conclusions}

Late Proterozoic-Cambrian paleopoles for Africa, with ages falling fully or partially within the interval 1150-500 Ma, have been compiled to assess their use in the testing of tectonic models (e.g. McWilliams, 1981; Piper, 1987). We conclude that the database is neither reliable enough to construct a common APWP for all of Africa, nor abundant enough to construct any but short APWP segments for the individual cratonic nuclei (Kalahari, Congo, West Africa ). The dataset comprises 64 paleopoles, only 26 of which have a quality factor $(Q)$ higher than 3 , and only 15 of which have sufficiently well-determined ages. While 
this does not imply that the tectonic models discussed in this paper are wrong, it does mean that paleomagnetic support for them is generally insufficient and that further work to obtain high-quality paleomagnetic results with accurate age determinations is urgently needed.

\section{Acknowledgements}

We thank Alex Halliday, Mike McElhinny, Mike McWilliams, Tullis Onstott, Henry Pollack and Ben van der Pluijm for valuable comments on the manuscript. Especially Mike McElhinny helped with clarifying (and correcting) some of the reliability information for many poles; we are also grateful that he and Bill Compston gave permission to publish critical age information in the Appendix. This research was supported by the Scott Turner Fund of the University of Michigan and by the Division of Earth Sciences, National Science Foundation, grant EAR 89-05811.

\section{Appendix}

Courtesy of William Compston (Australian National University) and Michael McElhinny, we have permission to publish the following $\mathrm{Rb} / \mathrm{Sr}$ age determinations on a sample from a dolerite intruding the rocks of the Van Dyke Consolidated Mine, Witwatersrand (pole 4, Table 1, footnote 3). For location, see McDougall (1963) who previously had dated the same sample (GA 148) with K/Ar techniques as approximately $1120 \mathrm{Ma}$. $\mathrm{Rb} / \mathrm{Sr}$ results have been obtained on K-feldspar separates also analyzed by McDougall, plus plagioclase from the same specimen.

$\begin{array}{llcll} & \begin{array}{l}\mathrm{Rb} \\ (\mathrm{ppm})\end{array} & \begin{array}{l}\mathrm{Sr} \\ (\mathrm{ppm})\end{array} & { }^{87} \mathrm{Rb} /{ }^{86} \mathrm{Sr} & { }^{87} \mathrm{Sr} /{ }^{86} \mathrm{Sr} \\ \begin{array}{l}\text { GA 148 } \\ \text { K-feldspar }\end{array} & 134.8 & 98.2 & 3.997 & 0.79826 \\ \begin{array}{l}\text { GA 148 } \\ \text { Plagioclase }\end{array} & 39.8 & 113.9 & 1.010 & 0.73016\end{array}$

The coefficient of variation for ${ }^{87} \mathrm{Rb} /{ }^{86} \mathrm{Sr}$ is $0.5 \%$ and for ${ }^{87} \mathrm{Sr} /{ }^{86} \mathrm{Sr}$ is $0.02 \%$.

The above data give a two-point isochron with an age of $1585 \mathrm{Ma}$ using the 1.42 decay constant, with $95 \%$ confidence limits of precision of $\pm 25 \mathrm{Ma}$ and a value of 0.7071 for initial ${ }^{87} \mathrm{Sr} /{ }^{86} \mathrm{Sr}$.

\section{References}

Abdullah, A., Nairn, A.E.M., Saving, D. and Sprague, K., 1984. Paleomagnetic study of some of the dikes from the Esh El Mellaha Range, Eastern Desert, Egypt. J. Afr. Earth Sci., 2: 267-275.

Allsopp, H.L., Kramers, J.D., Jones, D.L. and Erlank, A.J., 1989. The age of the Umkondo Group, eastern Zimbabwe, and implications for palaeomagnetic correlations. S. Afr. J. Geol., 92: 11-19.

Andersen, L.S. and Unrug, R., 1984. Geodynamic evolution of the Bangweulu Block, Northern Zambia. Precambrian Res., 25: 187-212.

Barnes, S.J. and Sawyer, E.W., 1980. An alternative model for the Damara Mobile Belt: ocean crust subduction and continental convergence. Precambrian Res., 13: 297-336.

Black, R., 1978. Propos sur le Pan-Africain. Bull. Soc. Geol. France, 20: 843-850.

Black, R., Caby, R., Moussine-Pouchkine, A., Bayer, R. Bertrand, J.M., Boullier, A.M., Fabre, J. and Lesquer, A., 1979. Evidence for late Precambrian plate tectonics in West Africa. Nature, 278: 223-227.

Briden, J.C., 1968. Paleomagnetism of the Ntonya Ring structure. J. Geophys. Res., 73: 725-733.

Briden, J.C., Duff, B.A. and Kröner, A., 1979. Paleomagnetism of the Koras Group, northern Cape Province, South Africa. Precambrian Res., 10: 43-57.

Brock, A., 1967. Palaeomagnetic result from the Hook Intrusives, Zambia. Nature, 216: 359-360.

Brock, A., Raja, P.K.S. and Vise, J.B., 1972. The palaeomagnetism of the Kisii Series, western Kenya. Geophys. J. R. Astr. Soc., 28: 129-137.

Bucur, I., 1971. Etude paleomagnetique d'une formation sedimentaire du Sahara algerien, d'age Cambro-Ordovicien. Ann. Geophys., 27: 255-261.

Burke, K., Dewey, J.F. and Kidd, W.S.F., 1976. Precambrian paleomagnetic results compatible with contemporary operation of the Wilson cycle. Tectonophysics, 33: 287-299.

Camfield, P.A. and Cough, D.I., 1977. A possible Proterozoic plate boundary in North America. Can. J. Earth Sci., 14: 1229-1238.

Cavanaugh, M.D. and Seyfert, C.K., 1977. Apparent polar wander paths and the joining of the Superior and 
Slave provinces during early Proterozoic time. Geology, 5: 207-211.

Charlton, S.R., 1973. Limitations of the argon 39 method on Precambrian dolerites. 17th Ann. Report Res. Inst. Afr. Geol., Univ. Leeds, pp. 45-47.

Daly, L. and Pozzi, J.P., 1977. Determination d'un nouveau pole paleomagnetique africain sur des formations cambriennes du Maroc. Earth Planet. Sci. Lett., 34: 264-272.

Davies, J., Nairn, A.E.M. and Ressetar, R., 1980. The paleomagnetism of certain late Precambrian and early Paleozoic rocks from the Red Sea Hills, Eastern Desert, Egypt. J. Geophys. Res., 85: 3699-3710.

Fisher, R.A., 1953. Dispersion on a sphere. Proc. R. Soc. London, A217: 295-305.

Gibb, R.A., Thomas, M.D. and Mukhopadhyay, M., 1980. Proterozoic sutures in Canada. Geosci. Canada, 7: 149154.

Gough, D.I., 1956. A study of the palaeomagnetism of the Pilansberg dykes. Mon. Not. Roy. Astr. Soc. Geophys. Suppl., 7: 196-213.

Hailwood, E.A. and Tarling, D.H., 1973. Palaeomagnetic evidence for a proto-Atlantic Ocean. In: D.H. Tarling and S.K. Runcorn (Editors), Implications of Continental Drift to the Earth Sciences, Vol. 1. Academic Press, London, pp. 37-46.

Hargraves, R.B. and Onstott, T., 1980. Paleomagnetic results from some southern African kimberlites, and their tectonic significance. J. Geophys. Res., 85: 3587-3596.

Hoal, B.G., Harmer, R.E. and Eglington, B.M., 1986. RbSr geochronology of the middle to late Proterozoic Awasib Mountain terrane. Comm. Geol. Survey S.W. Africa/Namibia, 2: 53-59.

Hoffman, P.F., 1988. United Plates of America, the birth of a craton: early Proterozoic assembly and growth of Laurentia. Ann. Rev. Earth Planet. Sci., 16: 543-603.

Idnurm, M. and Giddings, J.W., 1988. Australian Precambrian polar wander: a review. Precambrian Res., 40/41: 61-88.

Irving, E., 1979. Paleopoles and paleolatitudes of North America and speculations about displayed terrains. Can. J. Earth Sci., 16: 669-694.

Irving, E. and Lapointe, P.L., 1975. Paleomagnetism of Precambrian rocks of Laurentia. Geosci. Canada, 2: 90-98.

Irving, E., Park, J.K. and Roy, J.L., 1972. Paleomagnetism and the origin of the Grenville Front. Nature Phys. Sci., 236: 344-356.

Jones, D.L., 1968. Paleomagnetism of the Premier Mine Kimberlite. J. Geophys. Res., 73: 6937-6944.

Jones. D.L. and McElhinny, M.W., 1966. Paleomagnetic correlation of basic intrusions in the Precambrian of southern Africa. J. Geophys. Res., 71: 543-552.

Key, R.M., Charsley, T.J., Hackman, B.D., Wilkinson, A.F. and Rundle, C.C., 1989. Superimposed Upper Proterozoic collision-controlled orogenies in the Moz- ambique orogenic belt of Kenya. Precambrian Res., 44: 197-225.

Kirschvink, J.L., 1980. The least-squares line and plane and the analysis of palaeomagnetic data. Geophys. $J$. R. Astr. Soc., 62: 699-718.

Kröner, A., 1977. Precambrian mobile belts of southern and eastern Africa - ancient sutures or sites of ensialic mobility? A case for crustal evolution towards plate tectonics. Tectonophysics, 40: 101-135.

Kröner, A., 1980. Pan African crustal evolution. Episodes, 2: 3-8.

Kröner, A., 1982. Rb-Sr geochronology and tectonic evolution of the Pan-African Damara belt of Namibia, southwestern Africa. Am. J. Sci., 282: 1471-1507.

Kröner, A., McWilliams, M.O., Germs, G.J.B., Reid, A.B. and Schalk, K.E.L., 1980. Paleomagnetism of late Precambrian to early Paleozoic mixtite-bearing formations in Namibia (South West Africa): the Nama Group and Blaubeker Formation. Am. J. Sci., 280: 942-968.

Leblanc, M. and Lancelot, J.R., 1980. Intepretation geodynamique du domaine pan-africain (Precambrien terminal) de l'Anti-Atlas (Maroc) a partir de donnees geologiques et geochronologiques. Can. J. Earth Sci., 17: 142-155.

Martin, H. and Porada, H., 1977. The intracratonic branch of the Damara Orogen in South West Africa. 1. Discussion of geodynamic models. Precambrian Res., 5: 311-338.

McDougall, I., 1963. Potassium-Argon age measurements on dolerites from Antarctica and South Africa. J. Geophys. Res., 68: 1535-1545.

McElhinny, M.W., 1966. The palaeomagnetism of the Umkondo Lavas, eastern Southern Rhodesia. Geophys. J. Roy. Astr. Soc., 10: 375-381.

McElhinny, M.W. and McWilliams, M.O., 1977. Precambrian geodynamics-A paleomagnetic view. Tectonophysics, 40: 137-159.

McElhinny, M.W., Briden, J.C., Jones, D.L. and Brock, A., 1968. Geological and geophysical implications of paleomagnetic results from Africa. Rev. Geophys., 6 : 201-238.

McWilliams, M.O., 1981. Palaeomagnetism and Precambrian tectonic evolution of Gondwana. In: A. Kroner (Editor), Precambrian Plate Tectonics. Elsevier, Amsterdam, Ch. 26, pp. 649-687.

McWilliams, M.O. and Kröner, A., 1981. Paleomagnetism and tectonic evolution of the Pan-African Damara Belt, Southern Africa. J. Geophys. Res., 86: 51475162.

Morel, P., 1981. Palaeomagnetism of a Pan-African diorite: a Late Precambrian pole for western Africa. Geophys. J. R. Astr. Soc., 65: 493-503.

Morris, W.A. and Carmichael, C.M., 1978. Paleomagnetism of some late Precambrian and lower Paleozoic sediments from l'Adrar de Mauritanie, West Africa. Can. J. Earth Sci., 15: 253-262. 
Onstott, T. and Hargraves, R.B., 1981. Proterozoic transcurrent tectonics. Nature, 289: 131-136.

Onstott, T., York, D. and Hall, C.M., 1984. Constraints on the motions of South American and African Shields during the Proterozoic: I. ${ }^{40} \mathrm{Ar} /{ }^{39} \mathrm{Ar}$ and paleomagnetic correlations between Venezuela and Liberia. Bull. Geol. Soc. Am., 95: 1045-1054.

Onstott, T., Hargraves, R.B. and Joubert, P., 1986a. Constraints on the tectonic evolution of the Namaqua province II: Reconnaissance palaeomagnetic and ${ }^{40} \mathrm{Ar} /$ ${ }^{39} \mathrm{Ar}$ results from the Namaqua province and Kheis Belt. Trans. Geol. Soc. S. Afr., 89: 143-170.

Onstott, T., Hargraves, R.B. and Reid, D.L., 1986b. Constraints on the tectonic evolution of the Namaqua province III: Palaeomagnetic and ${ }^{40} \mathrm{Ar} /{ }^{39} \mathrm{Ar}$ results from the Gannakouriep Dyke swarm. Trans. Geol. Soc. S. Afr., 89: 171-183.

Perrin, M. and Prevot, M., 1988. Uncertainties about the Proterozoic and Paleozoic polar wander path of the West African craton and Gondwana: evidence for successive remagnetization events. Earth Planet. Sci. Lett., 88: 337-347.

Perrin, M., Elston, D.P. and Moussine-Pouchkine, A., 1988. Paleomagnetism of Proterozoic and Cambrian strata, Adrar de Mauritanie, cratonic West Africa. J. Geophys. Res., 93: 2159-2178.

Pesonen, L.J., Torsvik, T.H., Elming, S.A. and Bylund, G., 1989. Crustal evolution of Fennoscandia-paleomagnetic constraints. Tectonophysics, 162: 27-49.

Piper, J.D.A., 1972. A palaeomagnetic study of the Bukoban System, Tanzania. Geophys. J. R. Astr. Soc., 28: 111-127.

Piper, J.D.A., 1974. Magnetic properties of the Cunene Anorthosite Complex, Angola. Phys. Earth Planet. Int., 9: 353-363.

Piper, J.D.A., 1975a. The palaeomagnetism of Precambrian igneous and sedimentary rocks of the Orange River belt in South Africa and South West Africa. Geophys. J. R. Astr. Soc., 40: 313-344.

Piper, J.D.A., 1975b. Palaeomagnetic correlations of Precambrian formations of east-central Africa and their tectonic implications. Tectonophysics, 26: 135-161.

Piper, J.D.A., 1976. Palaeomagnetic evidence for a Proterozoic super-continent. Philos. Trans. R. Soc. London, A 280: 469-490.
Piper, J.D.A., 1987. Palaeomagnetism and the continental crust. Open University Press, Milton Keynes, 434 pp.

Piper, J.D.A., 1988. Palaeomagnetic Database. Open University Press, Milton Keynes, 264 pp.

Porada, H., 1989. Pan-African rifting and orogenesis in southern to equatorial Africa and eastern Brazil. Precambrian Res., 44: 103-136.

Reid, A.B., 1968. A palaeomagnetic study of the Sijarira Group, Rhodesia. M. Phil. Thesis, University of London.

Roy, J.L., Morris, W.A., Lapointe, P.L., Irving, E., Park, J.K. and Schmidt, P.W., 1978. Apparent polar wander paths and the joining of the Superior and Slave provinces during early Proterozoic time: Comment. Geology, 6: 132-133.

Saradeth, S., Soffel, H.C., Horn, P., Muller-Sohnius, D and Schult, A., 1989. Upper Proterozoic and Phanerozoic pole positions and potassium-argon (K-Ar) ages from the East Sahara craton. Geophys. J., 97: 209 221 .

Shackleton, R.M., 1976. Pan-African structures. Philos. Trans. R. Soc. London, A280: 491-497.

Shackleton, R.M., Ries, A.C., Graham, R.H. and Fitches, W.R., 1980. Late Precambrian ophiolitic melange in the Eastern Desert of Egypt. Nature, 285: 472-474.

Smith, A.G. and Hallam, A., 1970. The fit of the southern continents. Nature, 225: 139-144.

Symons, D.T.A., 1989. Proterozoic collision of the Archean Slave and Superior cratons: the birth and death of APWP track 4 for North America. Intern. Assoc. Geomagnetism and Aeronomy, 6th Scientific Assembly, Exeter, UK, 24 July-August 4, 1989, Abstract Volume, p. 89.

Unrug, R., 1983. The Lufillian Arc: A microplate in the Pan-African collision zone of the Congo and the Kalahari cratons. Precambrian Res., 21: 181-196.

Van der Voo, R., 1990. The reliability of paleomagnetic data. Tectonophysics, 184: 1-9.

Zijderveld, J.D.A., 1967. AC demagnetization of rocks: analysis of results. In: D.W. Collison, K.M. Creer and S.K. Runcorn (Editors), Methods in Paleomagnetism. Elsevier, Amsterdam, pp. 245-286. 